\title{
THE LIVING TREE CONSTITUTIONALISM: FIXITY AND FLEXIBILITY
}

\author{
Imer B. FLORES*
}

Resumen:

En este artículo el autor sostiene que el "constitucionalismo del árbol viviente" de Waluchow constituye una "revolución copernicana en nuestro pensamiento", dado que proporciona no sólo una teoría del judicial review, sino una teoría general del judicial review y de la democracia. No obstante que el autor coincide en que en esta teoría de Waluchow existe un lugar para una metodología del common law, discrepa en caracterizarla como una que va de "abajo hacia arriba". Por lo tanto, el objetivo del artículo es resaltar la importancia del argumento principal del libro $A$ Common Law Theory of Judicial Review: The Living Tree por medio del cual se intenta proporcionar un mejor entendimiento de las garantías individuales y del judicial review, pero advertir una consecuencia innecesaria, es decir, reducir la explicación a una metodología del common law de "abajo hacia arriba". A su vez el autor pretende proporcionar una corrección amigable: identificar la moralidad política constitucional de la comunidad a través de un método que es tanto de "abajo hacia arriba" como de "arriba hacia abajo", metodología que se encuentra implícita en el libro de Waluchow.

* Professor-Researcher, Instituto de Investigaciones Jurídicas (IIJ), Universidad Nacional Autónoma de México (UNAM) (i.e. Legal Research Institute, National Autonomous University of Mexico). E.mail: imer@servidor.unam.mx. The author is grateful to Hazel Blackmore and Brian Burge-Hendrix for commentaries on an earlier draft; to Tom Campbell and Wil Waluchow, as well as other participants in two book panels, one held as a seminar at IIJ-UNAM in Mexico City and other as a special workshop at IVR World Congress in Krakow, where previous versions of this paper were presented, for further comments; and, finally, to Ronald Dworkin, Duncan Kennedy and Jeremy Waldron for discussions on this subject over the years. 


\title{
IMER B. FLORES
}

Palabras clave:

Constitucionalismo del árbol viviente, common law, teoría del judicial review, interpretación constitucional, Wil Waluchow.

\begin{abstract}
:
In this article the author claims that Waluchow's "living tree constitutionalism" constitutes a "copernican revolution in our thinking", because it provides not a mere common law theory of judicial review but a general theory of judicial review and of constitutional democracy. Although agrees that something like the common law methodology is at play here, disagrees on characterizing it as bottom-up. Accordingly, intends to praise the main aspiration of A Common Law Theory of Judicial Review: The Living Tree, i.e. to provide a better understanding of charters and judicial review in a constitutional democracy by "the living tree" metaphor; to appraise an unwarranted claim, i.e. to reduce it to the common law bottom-up methodology; and, to raise the alternative with a friendly amendment, i.e. to identify the community's constitutional political morality via, a method that is both bottom-up and top-down, which is already explicit -or at least implicit- in his account.
\end{abstract}

Keywords:

Living Tree Constitutionalism, Common Law, Judicial Review Theory, Constitutional Interpretation, Wil Waluchow. 
Accordingly, since nothing prevents the earth from moving, I suggest that we should now consider also whether several motions suit it, so that it can be regarded as one of the planets. For, it is not the center of all the revolutions.

Nicolaus COPERNICUS

SUMmARY: I. Introduction. II. "The Living Tree" Metaphor. III. Towards a better understanding of Charters and Judicial Review: The Debate. IV. Waluchow's Alternative: A Common Law Theory of Judicial Review. V. An Amendment to Waluchow's Alternative: A General Theory of Judicial Review and of Constitutional Democracy? VI. Other Institutional Forces and Requirements: Judges, Legislators, Other Legal Officials and Operators. VII. Conclusion.

\section{INTRODUCTION}

Taking the Constitution and the Charter Rights seriously is one of the aims of Wilfrid J. Waluchow's A Common Law Theory of Judicial Review: The Living Tree ${ }^{1}$ and testing the motions of what he claims to be a "Copernican revolution in our thinking" (213) is one of the ambitions of this article. Let me advance my hunch that it is indeed so and clarify that it is because "The Living Tree" is not merely "A Common Law Theory of Judicial Review", but much more than that "A General Theory of Judicial Review and of Constitu-

1 Waluchow, W. J., A Common Law Theory of Judicial Review: The Living Tree (2007). (Hereinafter the references to the book are included directly in the text and in between parentheses.) Vid. for a sketch of the arguments Waluchow, W. J. "Constitutions as Living Trees: An Idiot Defends", 43 Canadian Journal of Law and Jurisprudence, 207 (2005) and for a summary of the book Waluchow, W. J., "A Common Law Theory of Judicial Review", 1 Problema. Anuario de Filosofía y Teoría del Derecho, 117 (2007). Vid. also Hübner Mendes, Conrado, "Book Notice”, 66 The Cambridge Law Journal, 471 (2007). 
tional Democracy". And as such it is a sophisticated version of "Constitutionalism" capable of reconciling two competing needs: fixity and flexibility.

Accordingly, I intend: in the following two sections (II and III), to praise different aspects of his book; in the following one (IV), to appraise what I consider to be an unnecessary deviation that might have derailed him from his objective - or at least slowed down his movements toward it; in the next two (V and VI), to raise his original route with what I consider to be a better trail to get him back railed on the right track; and, in the last one (VII), to reproduce our main conclusion and enhance it with two questions for further inquiry.

In other words, I pretend: (1) to depict his main aspiration, i.e. to provide a better understanding of Charters and Judicial Review in a Constitutional Democracy by "the living tree" metaphor; (2) to disapprove of an unwarranted claim, i.e. to reduce "the living tree" metaphor to the common law bottom-up methodology; and (3) to re-develop his alternative with a friendly amendment, i.e. to identify the community's constitutional political morality via, a method that is both bottom-up and top-down, which is already explicit —or at least implicit - on it: not only by judges but also by legislators, including framers, amenders or reformers, and other legal officials and operators, as well as by lawyers and citizens, in a division of labour, which at the end will grant him the point.

\section{II. “The Living Tree” Metaphor}

I applaud the "living tree" metaphor as drawing the picture of a "living constitution" beyond the given portrait of a "dynamic constitution". ${ }^{2}$ A distinction is helpful: although,

2 Although there are different approaches to constitutional interpretation and not all accept the idea of the "living constitution", such as "originalism", its dynamic feature has increasingly gained acceptance. However, the allegory of a "dynamic constitution" is very limited. Consequently, I prefer — despite the ongoing criti- 
living beings/things and non-living beings/things can be more or less dynamic, the latter are much more limited than the former. A machine can be set in motion and stopped, i.e. turned on and turned off, by someone or something, in more or less expected and foreseen ways, whereas an organism has a life of its own and so is capable of (re)acting in different unexpected and unforeseen ways. Appropriately, we can forecast - with a higher degree of certainty as an almost accurate prediction - what will happen to a mechanism, which has just been replaced a piece; while we can only foretell — with a lower degree of probability as a more or less approximate prophecy - what will happen to a patient, who has just been transplanted an organ. ${ }^{3}$

cism mainly from the originalists - the "living constitution" as portrayed in the "living tree" analogy. Vid. Beard, Charles A., "The Living Constitution", 185 Annals of the American Association of Political and Social Sciences, 29 (1936); Fallon Jr., Richard H., The Dynamic Constitution. An Introduction to American Constitutional Law (2004); and Waluchow, W. J., Inclusive Legal Positivism, 67 (1994): "[J]udges should view the constitution as a 'living tree' and interpret it in ways which express an ever-changing view and developing political morality". Cfr. Bork, Robert H., "Neutral Principles and Some First Amendment Problems", 47 Indiana Law Journal, 1 (1971); id., The Tempting of America. The Political Seduction of the Law (1990); Rehnquist, William H., "The Notion of a Living Constitution", 54 Texas Law Review, 693 (1976); Scalia, Antonin, "Common-Law Courts in a Civil-Law System: The Role of the United States Federal Courts in Interpreting the Constitution and Laws and Response", in Scalia, Antonin, A Matter of Interpretation. Federal Courts and the Law, 3-47 and 129-149 (1997); Scalia, Antonin, A Living Constitution Doesn't Exist, in http://newsarchives.tamu.edu/stories/05/050505-10.html, on one side; and, Ackerman, Bruce, "The Living Constitution", 120 Harvard Law Review, 1737 (2007); Balkin, Jack M., Alive and Kicking. Why No One Truly Believes in a Dead Constitution, in: http://www.slate.com/id/2125226/; id., Synthesizing Originalism and Living Constitutionalism, in http://balkin.blogspot.com/2005/08/synthesizing-origi nalism-and-living.html; id., Confusion about Originalism?, in http:// balkin. blogspot.com/2006/08/confusion-about-originalism. html; Kavanagh, Aileen, "The Idea of a Living Constitution", 16 Canadian Journal of Law and Jurisprudence, 55 (2003); Leiter, Brian, Originalism Redux, in http://leiterreports.typepad.com/ blog/2005/06/originalism_red.html; id., "Originalism Redux" Redux (with a reply to Solum) in http://leiterlawschool.typepad.com/leiter/2006/08/origina lism_red. html; and, Sager, Lawrence, "The Incorrigible Constitution", 65 New York University Law Review, 893 (1990), on the other.

3 Elsewhere I have pointed out the intrinsic limitations of thinking of law -and for that purpose the constitution and its reconstitution via constitutional reenactments and amendments or reforms - in merely mechanic-physical terms. Vid. Flores, Imer B., "Reconstituting Constitutions - Institutions and Culture. The Mexican Constitution and NAFTA: Human Rights vis à vis Commerce”, 17 Florida 
Following the distinction we can aptly say that the constitution is "a tree that is very much alive" (69) -and I might add - "and kicking" — to follow one of Professor Jack M. Balkin's indications. ${ }^{4}$ It is a "living thing" and capable of "organic growth", i.e. "a living tree capable of growth and expansion within its natural limits" (183); and, as a consequence, a constitution is "an instrument that must, within limits inherent in its constitutional role, be allowed to grow and adapt to new contemporary circumstances and evolving normative beliefs, including those about justice" (id.). 5 In a nutshell, it is a tree which has not only fixed and stable (or entrenched and written) roots as a modest and tentative pre-commitment, but also flexible and adaptable branches to be continuously re-fixed (or to be re-entrenched and re-written) as a further commitment that dialectically and dialogically will serve as a still modest and tentative pre-commitment, and so on.

Let me bring to mind that "the living tree" metaphor was introduced by Lord John Sankey in Edwards $v$. Attorney General of Canada, ${ }^{6}$ also known as the "Persons Case". This case was decided in 1930 by the Judicial Committee of the Privy Council of the United Kingdom, as the highest court

Journal of International Law, 693, 695-698 (2005). Somehow an organic-biological correlation is much more promising. Cfr. Hayek, Friedrich A. von, The Constitution of Liberty, 70 (1960): "Our attitude ought to be similar to that of the physician toward a living organism: like him, we have to deal with a self-maintaining whole which is kept going by forces which we cannot replace and which we must therefore use in all we try to achieve. What can be done to improve it must be done by working with these forces rather than against them. In all our endeavor at improvement we must always work inside this given whole, aim at piecemeal, rather than total, construction, and use at each stage the historical material at hand and improve details step by step rather than attempt to redesign the whole."

4 Another of his insinuations, relevant to this paper, in Balkin, "Alive and Kicking...", supra note 2, is: "We are all living constitutionalists now. But only some of us are willing to admit it."

5 Cfr. Justice Louis D. Brandeis inspiration quoted (from Brandeis Papers, Harvard Law School) by Brennan, William J., "Why Have a Bill of Rights?", 9 Oxford Journal of Legal Studies, 425, 426 (1989): "Our Constitution is not a straight jacket. It is a living organism. As such, it is capable of growth or expansion and adaptation to new conditions. Growth implies changes, political, economic and social."

6 Edwards v. Attorney General of Canada, A.C. 124 (1930). 
of appeals for several independent Commonwealth countries. It recognized for Canadians as already implicit in $\mathrm{Ca}-$ nadian Law "something like the right to equality before and under the law" (2). By the by, its integration took place more than half a century before its explicit inclusion or incorporation in the Canadian Charter of Rights and Freedoms, as Part I of the Constitution Act, in 1982.7

Moreover, the notion of the "living constitution" as a "living tree" can be traced back to Chief Justice John Marshall, who in McCulloch v. Maryland (1819) recalled the nature of the constitution and its interpretation: "[W]e must never forget that it is a constitution we are expounding... [a constitution does not] partake of the prolixity of a legal code... a constitution, intended to endure for ages to come, and, consequently, to be adapted to the various crises of human

7 Canada has by now - to use Roscoe Pound's categorization- the first 25 years of a living constitution "in books" but more than 75 years of a living constitution "in action". Vid. Pound, Roscoe, "Law in Books and Law in Action", 44 American Law Review, 12 (1910).

My guess is that the fact that "most of the rights included in the Charter enjoyed, in some form or other, recognition in Canadian law before the introduction of the Charter" falsifies both exclusive and inclusive legal positivism altogether by demonstrating both that law does neither exclude necessary references to morality as a criteria for legal validity nor merely may include/incorporate contingent references, but that law really includes/incorporates or even, for short, integrates necessary references to morality, i.e. in this case to principles and rights, at least implicit and long before its explicit recognition. The fact that law integrates necessary references to morality, therefore, does entail that law must integrate such references and does not mean that law is exhausted by those references. How come exclusive and inclusive legal positivists explain that Canadian law integrated as already implicit by 1930 , most — or even some - of the rights recognized as explicit until 1982? In my opinion, it neither is a contingency or particularity of some legal systems, such as the Canadian or those that belong to the common law tradition, nor is an exercise of a directed power to create or invent new law, but a necessity or generality of all legal systems to recreate or interpret the already existing law: if a legal system recognizes a prerogative or right to a specific group or kind of persons such as "men" and there is not only the same reason to integrate "women" into that group or kind but also no justified reason (functioning as a constraint or restraint) for not doing so, the legal system not eventually may include/incorporate but actually must integrate —or integrates - them as already implicit bear holders of such prerogative or right following the Latin adagio ubi eadem ratio, ibi eadem iuris dispositio.

I am very grateful to Brian Burge-Hendrix for pushing me to clarify this point. 
affairs."8 In a similar fashion, one century after, Justice Oliver Wendell Holmes Jr., in his dissent in Abrams $v$. United States (1919), recollected: "[O]ur Constitution... is an experiment, as all life is an experiment." ${ }^{9}$ And, one year later, in Missouri $v$. Holland (1920), remembered: 10

When we are dealing with words that are also a constituent act, like the Constitution of the United States, we must realize that they have called into life a being the development of which could not have been foreseen completely by the most gifted of its begetters. It was enough for them to realize or to hope that they had created an organism; it has taken a century and has cost their successors much sweat and blood to prove that they created a nation. The case before us must be considered in the light of our whole experience and not merely of what was said a hundred years ago.

Likewise, in those same years, Dean Roscoe Pound advanced -in his lectures at Trinity College, Cambridge University, in 1922 - and reminded later -in his lectures at the School of Law, University of Georgia, in 1959:11

8 McCulloch v. Maryland, 17 U.S. 316, 407, 415 (1819).

9 Abrams $v$. United States, 250 U.S. 616, 630 (1919). Cfr. Holmes Jr., Oliver Wendell, "Book Notices", 14 American Law Review, 233, 234 (1880) ("Book Notice" to the Second Edition of A Selection of Cases of the Law of Contracts with a Summary of the Topics covered by the Cases by C.C. Langdell): "Mr. Langdell's ideal in the law, the end of all his striving, is the elegantiajuris, or logical integrity of the system as a system. He is perhaps the greatest living theologian. But as a theologian he is less concerned with his postulates than to show that the conclusions from them hang together... so entirely is he interested in the formal connection of things, or logic, as distinguished from the feelings which make the content of logic, and which actually shaped the substance of the law. The life of the law has not been logic: it has been experience. The seed of every new growth within its sphere has been felt necessity. The form of continuity has been kept up by reasonings purporting to reduce every thing to a logical sequence; but that form is nothing but the evening dress which the new-comer puts on to make itself presentable according to conventional requirements. The important phenomenon is the man underneath it, not the coat; the justice and reasonableness of a decision, not its consistency with previously held views." (Emphasis added.) And Holmes Jr., Oliver Wendell, The Common Law, 1 (1881): "The life of the law has not been logic: it has been experience."

10 Missouri $v$. Holland, 252 U.S. 416, 433 (1920).

11 Pound, Roscoe, Interpretations of Legal History, 1 (1923) (republished: 1946) and Pound, Roscoe, Law Finding Through Experience and Reason, 23 (1960). 
Law must be stable and yet it cannot stand still. Hence all thinking about law has struggled to reconcile the conflicting demands of the need of stability and of the need of change. The social interest in the general security has led men to seek some fixed basis for an absolute ordering of human action whereby a firm and stable social order might be assured. But continual changes in the circumstances of social life demand continual new adjustments to the pressure of other social interests as well as to new modes of endangering security. Thus the legal order must be flexible as well as stable. It must be overhauled continually and refitted continually to the changes in the actual life which it is to govern. If we seek principles, we must seek principles of change no less than principles of stability. Accordingly the chief problem to which legal thinkers have addressed themselves has been how to reconcile the idea of a fixed body of law, affording no scope for individual wilfulness, with the idea of change and growth and making of new law.

Similarly, Justice Benjamin N. Cardozo, in The Growth of the Law - the sequel to his famous The Nature of the Judicial Process - formulated: "The law of our day faces a twofold need. The first is the need of some restatement that will bring certainty and order out of the wilderness of precedent. This is the task of legal science. The second is the need of a philosophy that will mediate between the conflicting claims of stability and progress, and supply a principle of growth." 12 And, finally, it was H.L.A. Hart who recapitulated: 13

In fact all systems, in different ways, compromise between two social needs: the need for certain rules which can, over great areas of conduct, safely be applied by private individuals to themselves without fresh official guidance or weighing up of social issues, and the need to leave open, for latter settlement by an informed, official choice, issues which can

12 Cardozo, Benjamin N., The Growth of the Law, 1 (1924). Cfr. Cardozo, Benjamin N., The Nature of the Judicial Process (1921).

13 Hart, H. L. A., The Concept of Law, 127 (1961) and 130-131 (2nd ed., 1994). 
only be properly appreciated and settled when they arise in a concrete case.

To summarize the importance of the idea and implications of finding a balance or equilibrium between the competing needs for fixity and flexibility, i.e. the Copernican revolution claimed by Waluchow, let me cite him: "The living tree conception brings these two approaches together into a kind of common law understanding of Charters - one that seeks to combine both the relative fixity of entrenched, written law and the relative adaptability [i.e. flexibility] characteristic of the common law." (183)

\section{TOWARDS A BetTER UndERSTANDING OF CHARTERS and Judicial Review: The Debate}

In the book Waluchow addresses two sets of different, but connected, questions related to the role and desirability of both Charters and Judicial Review in a Constitutional Democracy (13) and as a result, analytically, separates four questions (128). Furthermore, the book is divided into two parts: the first consisting of Chapters 1 to 4 , where he frames - or re-frames- the debate; and, the second containing Chapters 5 and 6, where he fosters his alternative. Let me repeat that in this section we will analyze some aspects related to his framing - or reframing - of the debate and in the following ones we will criticize his alternative, at least something in its core, and recognize an alternate route to it. It is worth mentioning that it contains helpful analytical distinctions to understand the importance of the debate and the need to transcend it.

On the one hand, from the different distinctions made by Waluchow - such as Rex-Regina (20-21), sovereign/ government (20-21, 25-27), (constitutionally) limited/unlimited (19-21), substantive limits/procedural requirements (22), constitutional law/constitutional convention (28-30), normative/de facto freedom (36-37), entrenched/non-entrenched 
rules (41-46), written/unwritten rules (47-52), constitutional interpretation/constitutional theories (52-73), Regas/Demos (76-79), representative democracy/constitutional democracy (79-81), Hercules/ Ulysses, re-labelled here as Atticus (97-99, 103-106, 109- 115), 14 Athenia/Venusians (97-99), procedural conception of democracy/constitutional conception of democracy (106-109), authentic or genuine wishes / unauthentic or not genuine ones (85-91), expressed wishes/ best interests (91-97), moral commitments/moral opinions (225-226), people- then/people-now $(18,136)$, tacit/hypothetical consent (142), top-down/bottom-up methodologies (204-208), hubristic/hum- ble messages (246) and so onin the coming paragraphs I will accentuate two distinct sets.

In the first, by acknowledging that a sovereign must be "constitutionally unlimited" 15 and a government can be "constitutionally limited" (24), Waluchow indicates that it is possible to differentiate two distinct kinds of sovereigns embodied by Rex (i.e. an unlimited sovereign with a constitutionally unlimited government) and Regina (i.e. an unlimited sovereign with a constitutionally limited government): "Regina has all the powers possessed by Rex, except that she lacks authority to legislate on matters concerning reli-

14 On behalf of Atticus Finch, i.e. the main character of the fictional novel of Lee, Harper, To Kill the Mockingbird (1960), a lawyer, brutally honest, highly moral, and a tireless crusader for good causes - even hopeless ones. Although I am sympathetic with the idea of legal officials, including lawyers and citizens, resembling Atticus Finch's highly ethical and moral approach to law, I fear that both legislators are not - or do not tend to be- as him and judges are not —or do not tend to be- like him. In short, we must assume that they neither are nor need to be Atticus.

15 Vid. Hobbes, Thomas, Leviathan, Ch. 29, 224 (Richard Tuck ed., 1991): "For to be subject to Lawes, is to be subject to the Common-wealth, that is to the Soveraign Representative, that is to himselfe; which is not subjection, but freedome from the Lawes. Which errour, because it setteth the Lawes above the Soveraign, setteth also a Judge above him, and a Power to punish him; which is to make a new Soveraign; and again for the same reason a third, to punish the second; and so continually without end, to the Conusion, and Dissolution of the Common-wealth." Vid. also Austin, John, The Province of Jurisprudence Determined, 254 (1954): "Supreme power limited by positive law, is a flat contradiction in terms." 
gion, and on any day except Wednesday." (21) As he highlights (25):

[W]e can coherently go on to speak of limited government coupled with unlimited sovereignty. This is presumably what one should say about constitutional democracies wherein the people's sovereign authority - what is usually termed "popular sovereignty" - is said to be unlimited but the government bodies - for example, Parliament or Congressthrough whom that sovereignty is exercised on the people's behalf is thought to be constitutionally limited...

And, as he later underlines (37):

Regina might be said to exercise limited government powers on behalf of an unlimited sovereign people who have entrusted her with various responsibilities... such picture underlies the traditional conception of constitutional democracies according to which government is held, in trust, by the various organs of government that are expected to observe a variety of constitutional limits. Failure to observe the required limits will nullify any attempt to exercise government power.

The existence of both substantive limitations (i.e. not legislating on matters concerning religion) and procedural limits (i.e. legislating on any day except Wednesday) reinforces an idea central to constitutionalism, such as the idea of a constitutionally limited government: "This is the idea... that government can and should be legally limited in its powers, and that its authority depends on its observing these limits" (9) and that "a constitution consists of one or more rules or norms constituting, and defining the limits (if any) of, government authority." (19) In other words, in democracies the power of the government and of the majority can be limited by the constitution, when it imposes both explicit substantive constraints on what can be decided and procedural restraints on how to decide and who is entitled to do it.

But the open questions are: (1) can there be a truly unlimited sovereign with a constitutionally unlimited govern- 
ment, such as the one embodied by Rex?; and (2) are there implicit limits to which an unlimited sovereign is subjected while governing, to the extent that all government is per definitio limited, especially under a constitution? To answer to both let me call your attention to the memorable Sunday morning of the 10th of November 1612, in which the judges of England were summoned before King James I upon complaint of the Archbishop of Canterbury to expound the alleged royal prerogative of the king to take away from the judges any cause he pleased and decided it himself, following the Latin adage: Quod principi placuit vigorem legis habet (i.e. "Whatever pleases the prince has the force of law"), as Pound recalled: 16

To this Coke answered on behalf of the judges, that by the law of England the king in person could not adjudge any cause; all cases, civil and criminal, were to be determined in some court of justice according to the law and custom of the realm. "But," said the king, "I thought law was founded upon reason, and I and others have reason as well as the judges." "True it was," Coke responded, "that God has endowed his Majesty with excellent science and great endowments of nature; but his Majesty was not learned in the laws of his realm of England, and causes which concern the life or inheritance or goods or fortunes of his subjects are not to be decided by natural reason, but by the artificial reason and judgment of the law, which law is an art which requires long study and experience before that a man can attain to the cognizance of it." At this the king was much offended, saying that in such case he should be under the law, which it was treason to affirm. Coke answered in the words attributed to Bracton, that the king ought not to be under any man but under God and the law [, i.e. non sub homine sed sub Deo et lege].

16 Vid. Pound, Roscoe, The Spirit of the Common Law, 60-61 (1921). Vid. also Flores, Imer B., "The Quest for Legisprudence: Constitutionalism $v$. Legalism", in The Theory and Practice of Legislation. Essays on Legisprudence, 43-44 (Luc J. Wintgens ed., 2005). 
In the second, with the distinctions between expressed wishes/best interests, authentic or genuine wishes/ unauthentic or not genuine ones, and moral commitments/moral opinions, Waluchow insinuates that a judge is not required to defer to the inauthentic moral opinions of the community - and even of the majority - but only to follow the authentic moral commitments of it -and even of they - not his or her own. By the same token, a legislator is not required to abide by the inauthentic moral opinions of the community - and even of the majority - but only to adhere to its - and even their- authentic moral commitments.

To reinforce his distinctions and the conditions that must be met, Waluchow invites us: first, in the case of a patient, who is fully informed about her medical condition and the options available, but that opts to say that she wants to die, to consider that (87):

[A] daughter is moved to declare: "I know what she just said, but that can't be my mother talking! She says she wants to die, but she has always firmly believed in a duty to God to preserve one's life at all costs. To surrender to death in this way would be, in her eyes, to insult God - something she would never, ever wish to do." In such a case, the patient might be described as speaking out of character. One might go so far as to say that in such cases of "evaluative dissonance" it is "her condition" speaking, not her. If so, then one might be inclined to say that her consent cannot possibly be valid because it is inauthentic.

And, second, to suppose the case of someone in a drunken state, who despite of being fully aware of the risks involved in drunk driving and the extent to which such conduct violates his fundamental convictions and settled preferences expresses his desire to drive himself home driven by a temporary, drink-enhanced, macho preference or impulse to get himself home under his own steam, but since that is an inauthentic wish his friends are justified not only 
in discounting or ignoring it but also in taking the car keys away to prevent him from driving (88-90).

In a similar way, the duty of legislators - and mutatis mutando of judges - is to follow the authentic moral commitments of the citizens, i.e. objective principles, and not their own subjective preferences. Representatives have an obligation to vote "as constituents would have voted under ideal conditions of deliberation - that is, with full knowledge of all relevant facts, and in the absence of prejudice or other factors that can cloud judgment, and so on" and "in whatever way is likely to advance the overall interests of her constituents" (16).

For this reason, their duty is not merely to follow expressed wishes of the community - and even of the majority- because those wishes not only may be harmful to it -or at least to a significant part of it such as a minoritybased on the notion of maximizing the utility of the majority and minimizing the one of the minority by appealing to the "greatest good of the greatest number", the so-called "tyranny of the majority", but also may be based in "simple prejudice" and even "fear of the other/unknown" (99-103). In fact, as Waluchow accentuates, on one side, for legislators (104): "Given all this, it seems quite reasonable to think that Atticus will deny that his duty lies in following the expressed wishes of his constituents. Only a naïve view of a representative's role would lead him to think otherwise." And, emphasizes, on the other, for judges (230):

In ruling against a government action (e.g. a statute or judicial ruling) that has the support of popular moral opinion, judges might actually be enforcing, not thwarting, the community's very own political morality [i.e. moral commitment]... and a court, in upholding these elements of the community's constitutional morality, will not only be respecting the community's authentic wishes and commitments, it will in fact be upholding the law.

To review the transcendence of this idea and its applicability to both legislators and judges, i.e. the Copernican rev- 
olution claimed by Waluchow, let me, first, draw a parallel: Did Copernicus have to accept the explicit or expressed inauthentic opinion of the community - and even of the majority - regarding the virtually unanimous acceptance of the belief that the middle of the universe is the earth or to assume the implicit or tacit authentic commitment of the community - and even of both the majority and the minority - to truth, i.e. that the middle of the universe is the sun? And, now, quote him (237):

[T] he role of judges is not to bow to the inauthentic wishes of the majority and enforce their misguided moral opinions and evaluative dissonance, any more than it was Atticus's job to bow to the misguide wishes of his constituents. Their job is to respect and enforce the true commitments of the community's constitutional morality in reflective equilibrium.

On the other hand, the book includes an exhaustive and extensive analysis and criticism of all the arguments, claims, examples, and objections, embedded in the standard case for Judicial Review, as well of all counter-arguments, counter-claims, counter-examples, and counter-objections, implanted in the critics' case against it, such as the "Argument from Democracy" and the "Argument from Disagreement". The former implies that "Democratic principle is seriously compromised if unelected and politically unaccountable judges are left with the task of fleshing out the contours of the moral rights the Charter claims to guarantee, and then applying these rights against legislation duly passed by democratically accountable bodies like Parliament and the provincial legislatures" (3-4). ${ }^{17}$ The latter invites us to believe that "Yet if members of a community cannot agree, at any particular moment in time, let alone across generations, on the nature and content of the moral rights enshrined in their Charter, they cannot intelligibly

17 Elsewhere I have responded to this argument, vid. Flores, Imer B., "Assessing Democracy and Rule of Law: Access to Justice", in 1 Proceedings of the $21^{\text {st }}$ IVR World Congress, 146 (Aleksander Peczenik ed., 2004). 
pre-commit to the stable, fixed point of constitutional limits within which government power is supposed to be exercised on their behalf." (125) 18

In fact, it is hard to imagine, even one single argument, claim, example, or objection and their corresponding counter-argument, counter-claim, counter-example, or counterobjection, made by both the advocates and the critics of written entrenched Charters and Judicial Review, such as Ronald Dworkin and Jeremy Waldron, respectively, or any other authors known, left out.19

After an exposition of both the standard case and the critics' case, Waluchow starts an exploration of the possible routes for an ongoing debate. Instead of talking past each other as no threat or thwart has been imposed unto the road, he decided - rather than taking a long detour or a short-cut taking him nowhere - to face the dangers and obstructions blocking the road ahead. Faced with the option of abandoning entrenched written Charters and Judicial Review altogether as Waldron advised - or at least somewhat as Tom Campbell advocated, by adopting a legislative Bill of Rights to be enforced not by courts but by legislatures-20 Waluchow fosters an alternative to it, which constitutes "a better understanding of the nature and role of... [Charters and Judicial Review] within a constitutional democracy." (14)

18 Vid. Waldron, Jeremy, Law and Disagreement, 295 (1999): "it looks as though it is disagreement all the way down, so far as constitutional choice is concerned."

19 Vid. Dworkin, Ronald, Taking Rights Seriously (1977) (2 ${ }^{\text {nd }}$ ed., 1978), A Matter of Principle (1985), Law's Empire (1986), Freedom's Law. The Moral reading of the American Constitution (1996), and Justice in Robes (2006). Vid. also Waldron, Law and Disagreement, supra note 18; and Waldron, Jeremy, The Dignity of Legislation (1999).

20 Cfr. Campbell, Tom, "Legislating Human Rights", in The Theory and Practice of Legislation: Essays on Legisprudence, supra note 16, at 219. Even though, Waluchow does not expressly address the issue there are hints that he does tacitly reject the alternative, by referring to Attorney General of Canada v. Lavell, S.C.R. 1349 (1974) as a case "sometimes cited as evidence that a purely statutory nonconstitutional Bill of Rights is an ineffective tool for the protection of rights." (3 fn 9). 
IV. Waluchow's Alternative: A Common Law Theory OF JUDICIAL REVIEW

From my point of view Waluchow's alternative is very appealing, counting most of the premises and conclusions. However, I have a small problem with one of the premises (someone might even think that it is a conclusion in itself). My intuition is that this premise (or conclusion) is unnecessary for the main objective. I refer mainly to something within the core of the fifth chapter.

Throughout the book Waluchow has been formulating powerful arguments not only for a better understanding of Charters Rights and Judicial Review in a Representative Democracy (or for those having a Procedural Conception of Democracy) but also for limited government in a Constitutional Democracy (or for those holding a Constitutional Conception of Democracy). In the latter, legislation and adjudication, legislatures and courts, and legislators and judges are compatible working with their respective limits and powers not merely functioning as a control on each other but coexisting as a complement in a division of labour.

More precisely, the problem is with circumscribing the alternative to the common law methodology, which is characterized as a bottom-up one to meet the challenge that disagreement comes all the way down: suggesting that it is possible to revise Charter Rights by Judicial Review at the point of their application and to re-elaborate them all the way up as judge made-law. The approach echoes Hart's to-thecentre moves — which resemble Aristotle's middle term. Let me rephrase it: common law is revisable at the point of application, whereas statutory law is not. Charter Rights, which resemble fixed statutory law in the sense that they are entrenched and written, require a flexible application similar to the one of common law. Hence, the common law bottom-up methodology appears to be the way out. As I said, it seems to be all the way up to face disagreement all the way down. 
But this is not the case. It might be in Great Britain, where an un-entrenched and unwritten Charter may be constructed all the way up by judges alone - assuming legislators neither had say nor will say (or have to say) nothing at all- as judge made-law, but the idea of a purely common law constitutionalism is highly contestable even there. ${ }^{21}$ Anyway, in my opinion, it is absolutely not the case for an entrenched written one, in which legislators, including framers, amenders or reformers, have a say: they have already said something and are entitled to say something else.

Bear in mind that in most countries Bills of Rights are, nowadays, not only both entrenched and written but also enforced, apparently, in common law countries with a purely common law methodology familiar to them. And, arguably, by those unfamiliar prima facie to such methodology, with a somewhat different one: 1) in non-common law countries, such as civil law ones, for example, Germany, Italy and Spain, as well as Argentina, Colombia and México; 2) in the rest of the world, by regional courts on human rights, such as the European, the Inter-American and the African; and, 3) in parts of common law countries with civil law backgrounds, for instance, Louisiana in the United States of America and Quebec in Canada.

Notwithstanding, it is clear that the differences between the common law and the civil law systems, together with their respective methodologies, tend to be exaggerated, overdrawn and overstated, whilst both systems are getting closer and resemble each other more every day. It might be argued, following Hart, that the former is more flexible than fixed, while the later is more fixed than flexible. But both,

21 On common law constitutionalism and its critique, vid. for example, T. R. S. Allan, "Constitutional Rights and Common Law", in Law, Liberty and Justice. The Legal Foundations of British Constitutionalism, 135-162 (1993); and Poole, Thomas, "Dogmatic Liberalism? T.R.S. Allan and the Common Law Constitution", 65 Modern Law Review, 463 (2002). I agree with Tom Campbell, in the sense that Wil Waluchow has to separate himself from a strong version of common law constitutionalism and defend a weak one. 
in dealing with precedents, have found a compromise between these two competing needs for fixity and flexibility. That's why it is possible to be thinking of a shared methodology and a much more similar method of reasoning all across the board. It is, certainly, "something like" the common law, but not the common law per se. In other words, it is something that all systems have in common or share -even though it is not necessarily the common law bottom-up methodology as such. How come those who are not versed in the common law methodology ended applying it?

I consider the use of the term "common law", especially in the title of the book, unfortunate for being confusing and misleading. The "common law" means either "judge madelaw", "custom of the whole realm" (i.e. the British Commonwealth, its colonies and territories), and/or "common reason". 22 In my opinion, entrenched and written Charter Rights are neither purely judge made-law (i.e. bottom-up methodology) nor can be circumscribed only to the common law countries, though the third sense can not be ruled out completely. It really implies "something like" a "common reason" such as Edward Coke's "artificial reason", which main features are characterized by Gerald Postema as: 1) pragmatic, 2) contextual, 3) nonsystematic, 4) discoursive, and 5) common or shared. ${ }^{23}$ But, it is far from being conclusive that nowadays entrenched and written Charter Rights are still non-systematic or wholly pragmatic.

Anyway, for the purpose of identifying the puzzling common law features, Waluchow quotes a précis made by Frederick Schauer in his book review of Melvin Aron Eisenberg's

22 Vid. Postema, Gerald, "Philosophy of the Common Law", in The Oxford Handbook of Jurisprudence \& Philosophy of Law, 588 (Jules Coleman and Scott Shapiro eds., 2002).

23 Id., at 593-595. Cfr. Coke, Edward, First Institute of the Laws of England, 97b (1628): "an artificial perfection of reason gotten by long study, observation, and experience, and not every man's natural reason; for nemo nascitur artifex." (Reprinted: 1979.) 
The Nature of the Common Law (197). ${ }^{24}$ In short, the rules of the common law: (1a) are nowhere canonically formulated or there is no single authoritative formulation; (2a) are not made by legislatures, but by courts; (3a) are created by courts in the very process of application (and applied retroactively to facts arising prior to the establishment of the rule); and (4a) are not only created interstitially but also modified or replaced when their application would generate a malignant result in the case at hand.

To the contrary, in my perspective, Charter Rights: (1b) are everywhere formulated, with open texture and vague terms that definitely do not provide a single straightforward authoritative formulation; (2b) are neither made by legislatures nor by courts alone, but drafted firstly into an authoritative source such as the Constitution and the Bill of Rights, or incorporated to them by means of constitutional conventions and constitutional amendments or reforms by its framers, amenders or reformers, and unquestionably redefined or remade by both legislatures and courts, via legislation and its application-interpretation in the process of adjudication; (3b) are not created out of the blue by courts in the process of application (and thus not necessarily applied retroactively), but surely revisable by them at the point of application; and (4b) are neither created interstitially nor modified or replaced, when their application would generate a malignant result in the case at hand -or at least not necessarily.

To prove these points, let me call to mind that the Constitution of the United States of America (1789) and the Bill of Rights (1791), originally, did not say anything about race and as such did not prohibit slavery; and, later, with Amendments, i.e. 13th (1865), 14th (1868) and 15th (1870), not only prohibited slavery but also granted equal rights and protected political rights of racial groups. Nevertheless, the Supreme Court continued to allow segregation and ra-

24 Vid. Schauer, Frederick, "Is the Common Law Law?", 77 California Law Review, 455 (1989). Cfr. Eisenberg, Melvin Aron, The Nature of the Common Law, (1988). 
cial discrimination, under the criteria of "separate, but equal" in Plessy v. Ferguson (1896). ${ }^{25}$ Not until Brown $v$. Board of Education (1954), ${ }^{26}$ the Court declared that segregation promoted discrimination and later on ordered school desegregation. Collaterally, this decision sparked legislators and legislatures to create affirmative action programs. These programs with decisions going back and forth have been held constitutional, due to the existence of a compelling state interest, ${ }^{27}$ unless when imposing quotas, such as in Regents of the University of California v. Bakke (1978). ${ }^{28}$ However, recently, in Parents Involved in Community Schools $v$. Seattle School District No. 1 (2007), ${ }^{29}$ a case argued December 4, 2006 and decided June 28, 2007, together with Meredith $v$. Jefferson County Board of Education, these programs were severely limited by a decision that restricted districts' ability to use race to assign students to school integration efforts. The question is whether this decision will put an end to the Brown era and to affirmative action programs altogether. Therefore, on this topic, as in any other, the discussion keeps going - and going - as the living tree keeps growing - and growing.

Furthermore, the common law methodology as such was not directed to deleting or subtracting rules from the system but to inserting and adding other rules to it. As Justice Scalia stated "It should be apparent that by reason of the doctrine of stare decisis... the common law grew in a peculiar fashion - rather like a Scrabble board. No rule of decision previously announced could be erased, but qualifications could be added to it." 30 On the contrary, following

25 Plessy $v$. Ferguson, 163 U.S. 537 (1896).

26 Brown $v$. Board of Education, 347 U.S. 483 (1954).

27 Vid. for instance, Adarand Constructors, Inc. v. Peña, 515 U.S. 200 (1995) and Grutter $v$. Bollinger, 539 U.S. 306 (2003).

28 Regents of the University of California v. Bakke, 438 U.S. 265 (1978). Cfr. Gratz v. Bollinger, 539 U.S. 244 (2003).

29 Parents Involved in Community Schools v. Seattle School District No. 1 (and Meredith $v$. Jefferson County Board of Education), 551 U.S. (2007).

30 Cfr. Scalia, "Common-Law Courts in a Civil-Law...", supra note 2 , at 8. 
with the living tree metaphor, it is possible to prune or trim some branches, i.e. to cut off and cut out some rules.

So far, there is no conclusive argument for sustaining that the common law bottom-up methodology is the defining one underlying Charter cases. Somehow it is true that by lacking a single straightforward formulation, due to the fact of being enacted - and re-enacted - with open texture and vague terms, Charter Rights require not only to be constantly revised at the point of application in case-by-case scenarios and from time-to-time, but also developed gradually, incrementally and progressively. Certainly, I am not ruling out that "something like" the common law methodology - or at least partially - plays a defining part and a key role here and elsewhere. Keep in mind Eisenberg introductory remarks: 31

My purpose here is to develop the institutional principles that govern the way in which the common law is established in our society [i.e. a Common Law country, such as the United States of America]. Much of our law derives from rules laid down in constitutions, statutes, or other authoritative texts that the courts must interpret but may not reformulate. The common law, in contrast, is the part of the law that is within the province of the courts themselves to establish. In some areas of law, like torts and contracts, common law rules predominate. In other areas, like corporations, they are extremely important. In all areas, even those that are basically constitutional or statutory, they figure at least interstitially.

Additionally, I can hardly imagine Waldron and Dworkin -or someone else for that effect- not coming after Waluchow for his moves. On the one hand, Waldron -or any other critic - might hold him accountable for not taking the legislators and legislatures seriously by not accommodating them into the theory. While conceding that Judicial Review is acceptable in situations that do not match

31 Eisenberg, The Nature of the Common Law, supra note 24, at 1. Cfr. Calabresi, Guido, A Common Law Review for the Age of Statutes (1981). 
his "core" case, he has still rejected the claim that judges are better positioned for moral insight than legislators: ${ }^{32}$

But this is mostly a myth. By the time the cases reach the high appellate levels we are mostly talking about in our disputes about judicial review, almost all trace of the original flesh-and-blood right-holders has vanished, and argument such as it is revolves around abstract issue of the right in dispute. Plaintiffs or petitioners are selected by advocacy groups precisely in order to embody the abstract characteristics that the groups want to emphasize as part of a general public policy argument...

The process of legislation is open to consideration of individual cases, through lobbying, in hearings, and in debate. Indeed, there is a tendency these days to initiate legislation on the basis of notorious individual cases - Megan's Law, for example. Hard cases make bad law, it is sometimes said. To the extent that this is true, it seems to me that legislatures are much better positioned to mount an assessment of the significance of an individual case in relation to a general issue of rights that affect millions and affects them in many different ways.

Why insist on judges and courts as the one and only final and infallible sole law-makers or interpreters of Charter Rights? What about legislators and legislatures? It does not suffice to affirm: "The result [of mixing Hart, Reaume, and Schauer] is our alternative model of Charters and their legitimacy, the common law conception, which in no way undermined by the circumstances of politics." (209)

32 Waldron, Jeremy, "The Core of the Case Against Judicial Review", 115 Yale Law Journal, 1346, 1379 (2006). Cfr. Moore, Michael S., "Law as a Functional Kind", in Natural Law Theory. Contemporary Essays, 188, 230 (Robert P. George ed., 1992): "[J]udges are better positioned for this kind of moral insight than are legislatures because judges have moral thought experiments presented to them everyday with the kind of detail and concrete personal involvement needed for moral insight. It is one thing to talk about a right to privacy in general, another to order a teenager to bear a child she does not want to bear. One might well think that moral insight is best generated at the level of particular cases, giving judicial beliefs greater epistemic authority than that possessed by legislative beliefs on the same subject." 
On the other hand, Dworkin - or any other advocate and even some critic- might hold him accountable for obscuring what judges and courts do by suggesting that it is all the way up flexible interpretation with no fixed constraint or restraint: Is it really a bottom-up methodology, all the way up flexible interpretation, regardless of the fixed, i.e. entrenched and written, character of Charters? I guess not. What's more, admitting that would be like saying that the living tree grows from the flexible branches towards the fixed roots and that will amount to throwing the baby out with the bath water.

In few words, my claim has been that "The Living Tree" is not merely "A Common Law Theory of Judicial Review", since it is much more: "A General Theory of Judicial Review and of Constitutional Democracy". On one side, it is a general theory beyond the boundaries of the common law system and its bottom-up methodology; and, on the other, it is not limited to the role that judges play in Judicial Review, but to their role in a Constitutional Democracy and its compatibility with the one played by legislators, including framers, amenders and reformers, as well as other legal officials and operators, such as lawyers and citizens.

Waluchow can easily answer to my objection by saying that (1) he is interested in developing a Common Law Theory of Judicial Review for common law countries with a common law bottom-up methodology; and (2) he is interested neither in a General Theory of Judicial Review nor for it to be applied to a Constitutional Democracy. However, I am certain that it is to the contrary, since he is truly interested in providing a better understanding of Charter Rights and Judicial Review, i.e. a general description-explanation, to be applied all across the board. But why label it as a common law judge made-law bottom-up methodology, when it is neither truly so nor need to be the case? It might be "something like" the common law, but not per se. In other words, something shared in common by all legal systems with —or without - entrenched written Charters Rights and 
Judicial Review. So, the quest for an amendment or reform to his alternative is indispensable.

\section{An Amendment to Waluchow's Alternative: \\ A General TheOry of Judicial REview \\ AND OF CONSTITUTIONAL DEMOCRACY?}

My friendly amendment, following Waluchow's Hartian move, can also be labelled as occupying the centre-middle. My claim is that, in Charter cases, we start with the interpretation of the text, a fixed entrenched and written Charter, but with open-texture and vague terms, something like a statutory law, top-down methodology; and, then, only then, we confront it - at the point of application- with "something like" a common law reason, by applying the bottom-up methodology, as Waluchow rightly claims.

It is neither all the way-down statutory law application by a judge completely deferential to whatever was said by the legislators -including framers, amenders or reformersnor all the way-up common law revision at the point of application by a judge entirely disrespectful to them. It is a different methodology, one that requires a meeting point, as the one provided by Waluchow himself in chapter sixth, i.e. identifying the community's constitutional morality, by using "something like" John Rawls' "reflective equilibrium" (223) —or even "something like" H.L.A. Hart's "critical reflective attitude". 33

In the case of entrenched and written Charters, one part is already fixed, as a sort of modest pre-commitment, but

33 Vid. Rawls, John, A Theory of Justice, 20-21, 48-51 (1971) and 18-19, 42-45 (1999). Hart, The Concept of Law, supra note 13, at 56 and 57. For a continental alternative to Rawls, vid. Habermas, Jürgen, "Reconciliation Through the Public Use of Reason: Remarks on John Rawls's Political Liberalism”, 92 Journal of Philosophy, 109 (1995); and Habermas, Jürgen, Between Facts and Norms. Contributions to a Discourse Theory of Law and Democracy (1996). Elsewhere I have criticized Hart's "critical reflective attitude" as developed uncritically by him and his disciples but endorsed the necessity of adopting the internal point of view and the neediness for a critical reflective attitude - or at least "something like" it. Vid. Flores, Imer B. "In the Dark Side of the Conventionality Thesis?", in Studies in Social, Political and Legal Philosophy. Philosophy of Law and of Politics, 155-156 (E. Villanueva ed., 2002). 
drafted in open-texture and vague terms, which require to be re-fixed, as a further commitment, i.e. adapted in caseby-case scenarios and from time to time by judges in a flexible manner but that does not mean that they are completely free. In fact, they are not only bound to some extent by their previous decisions but also constrained or restrained by the legislators.

Moreover judges are not alone in this and space must remain open for legislators, including framers, amenders or reformers, as well as other legal officials and operators, such as lawyers and citizens, to play a key role in other stages of the political process - or as Waldron puts it "in the circumstances of politics". ${ }^{34}$ Nevertheless, this complex methodology is compatible with the one portrayed, by some advocates of the standard case for Judicial Review, such as Dworkin's "constructive interpretation", "integrity model" and "moral reading of the constitution", comprising "fit" and "moral value/worth", or John Hart Ely's "representation reinforcement model", incorporating the representation of minorities at the same time of balancing the impossibility of a (strict) clause-bound interpretivism and the necessity of discovering fundamental values. ${ }^{35}$

34 Waldron, Law and Disagreement, supra note 18, at 102.

35 Vid. Dworkin, Taking Rights Seriously, supra note 19, and Law's Empire, supra note 19; and Hart Ely, John, Democracy and Distrust. A Theory of Judicial Review (1980). Cfr. United States v. Carolene Products Co. 304 U.S. 144 (1938), (especially its famous footnote 4 , which paved the way to the Warren Court and indeed inspired Ely's "representation reinforcement model"):

There may be narrower scope for operation of the presumption of constitutionality when legislation appears on its face to be within a specific prohibition of the Constitution, such as those of the first ten amendments, which are deemed equally specific when held to be embraced within the Fourteenth...

It is unnecessary to consider now whether legislation which restricts those political processes which can ordinarily be expected to bring about repeal of undesirable legislation, is to be subjected to more exacting judicial scrutiny under the general prohibitions of the Fourteenth Amendment than are most other types of legislation.

[...]

Nor need we enquire whether similar considerations enter into the review of statutes directed at particular religious $\ldots$ or national $\ldots$ or racial minorities ...: whether prejudice against discrete and insular minorities may be a special condition, which tends seriously to curtail the operation of those political processes or- 
This methodology requires keeping a complex balance not only between fixity and flexibility but also between fallibility and finality. In that sense, it is -and must be- open to allow other actors, besides judges, to play their respective roles. It implies a constant revision not merely at the point of application but undeniably at any other point in time; and requires the greater space available for a constructive and discursive deliberation and experimentation about the capacities for organic growth within its limits. In my opinion it is a methodology, which allows falsifying some (mis)interpretations and (mis)applications, counting with modifying or replacing them with better interpretations and applications -if not by the correct and right ones. It is something like the trial-and-error process of the natural, biological or physical sciences, proposed by Justice Brandeis, in his dissent in Burnet v. Coronado Oil \& Gas Co. (1932): 36

Stare decisis is not, like the rule of res judicata, universal inexorable command. 'The rule of stare decisis, though one tending to consistency and uniformity of decision, is not inflexible. Whether it shall be followed or departed from is a question entirely within the discretion of the court, which is again called upon to consider a question once decided.' Stare decisis is usually the wise policy, because in most matters it is more important that the applicable rule of law be settled than that it be settled right. This is commonly true even where the error is a matter of serious concern, provided correction can be had by legislation. But in cases involving the Federal Constitution, where correction through legislative action is practically impossible, this court has often overruled its earlier decisions. The court bows to the lessons of experience and the force of better reasoning, recognizing that

dinarily to be relied upon to protect minorities, and which may call for a correspondingly more searching judicial inquiry. (The emphasis is added.)

36 Burnet v. Coronado Oil \& Gas Co., 285 U.S. 393 (1932). Cfr. Brandeis, Louis D., "Experimentation and Trial and Error", in The Words of Justice Brandeis, 76 and 172 (Solomon Goldman ed., 1953): "The discoveries in physical science, the triumphs in invention, attest the value of the process of trial and error." 
the process of trial and error, so fruitful in the physical sciences, is appropriate also in the judicial function.

The process of trail-and-error describes and explains how an error in legislation is corrected by adjudication and vice versa, i.e. how a mistake in adjudication is later on rectified by courts themselves and prevented from happening again by further legislation, constitutional amendments or reforms. It is worth mentioning that the former does neither amount to "judicial legislation" nor constitutes a "judicial usurpation", as Lon L. Fuller said: "The correction of obvious legislative errors or oversights is not to supplant the legislative will, but to make that will effective." 37 In contrast the latter does neither amount to "legislative adjudication" nor constitutes a "legislative usurpation", as Fuller might say: "The correction - and prevention- of obvious adjudicative errors or oversights is not to supplant the judiciary will, but to make that will effective."

What I have in mind is that other institutions, with varying forces, come - and must come- into play to assure the constant and continuous participation of judges and of legislators, including framers, amenders or reformers, and of other legal officials and operators, such as lawyers and citizens, to the extent that contrary to the assumption "that the decision of a supreme court to overturn legislative decisions is absolute... Yet... there is no necessity here. It is possible to have judicial review without granting judges the final say." (12) In view of the fact that we do not know by all means whether legislators got —or will get- it right, it is a good idea to have Judicial Review to check them; but since we do not know of course whether judges got —or will getit right as well, it is a good idea to leave the process open for further revision or to ask for further institutional forces and requirements to come into play.

37 Fuller, Lon L., "The Case of the Speluncean Explorers", 112 Harvard Law Review, 1851, 1859 (1999) (Published originally in 61 Harvard Law Review, 616, (1949); and, republished in The Case of the Speluncean Explorers. Nine New Opinions 14 (Peter Suber ed., 1998). 
Waluchow mentions, in this book, for example, section 33 of the Constitution Act of Canada, i.e. the notwithstanding clause (12 and 130), and sections 4 and 7 of the Bill of Rights Act of New Zealand (129); and, in his previous one, i.e. Inclusive Legal Positivism, for instance, article 12 of the French Law of 16-24 August 1790 and article 256 of the French Constitution of 1790 (requiring the Courts to address the Legislative if it is necessary to interpret the law for a binding determination. ${ }^{38}$ In addition, I can point out the case of Mexico and its Federal Constitution: to article 72 , section $\mathrm{f}$, which empowers the legislative to issue, among other things, interpretative decrees; to article 105, which requires the vote of eight out of eleven justices that constitute the Supreme Court at large (or four out of five that constitute each one of the two benches) in some cases to have a general (derogatory) effect; and to article 135, which imposes a two thirds supra-majority of the members present in both chambers of Congress, discussing and approving it consecutively, plus the ratification of the absolute majority of the legislatures of the states for a constitutional amendment or reform to take place.

To sum up the importance and transcendence of the idea and implications of amending his alternative, with something already embedded into it, to maintain its sustainability, i.e. the Copernican revolution claimed by Waluchow, let me quote him (213):

Charters both can and should be seen to represent a mixture of only very modest pre-commitment and confidence, combined with a considerable measure of humility. The latter stems from the recognition that we - and this includes our representative legislators and all other charged with the

38 Vid. Waluchow, Inclusive Legal Positivism, supra note 2, at 241-242. Vid. also Waldron, "The Core of the Case Against Judicial Review", supra note 32, at 1356-1357; and, Marmor, Andrei, “Are Constitutions Legitimate?", 1 Problema. Anuario de Filosofía y Teoría del Derecho, 73, 114-115 (2007) (Published originally as: "Are Constitutions Legitimate", 20 Canadian Journal of Law and Jurisprudence, 69 (2007).) 
task of rendering law-determining decisions on our behalfdo not in fact have all the answers when it comes to moral rights and the impact of our actions on them, and that we should do all we can to ensure that our moral short-sightedness and other limitations do not, in the circumstances of politics and rule making, lead us to morally unworthy government action, understood, once again, as encompassing legislative, executive, and judicial acts.

Far from being based on the unwarranted assumption that we can have, in advance, all the right answers to the controversial issues of political morality that might arise under Charter challenges to government action, and that we are warranted in imposing these answers on those by whom we are succeeded, the common law conception stems - and it is this which leads me to claim that it represents a kind of Copernican revolution in our thinking- from the exact opposite sentiment: from a recognition that we do not have all the answers, and that we are well advised to design our political and legal institutions deliberately in ways that are sensitive to this feature of our predicament.

\section{OTHER INSTITUTIONAL FoRCES AND REQUIREMENTS: JUDGES, LEGISLATORS, OTHER LEGAL OFFICIALS AND OPERATORS}

Any successful alternative has not only to cope with fixity and flexibility but also deal with fallibility and finality. Judicial Review, especially in a Constitutional Democracy, is necessary to check the fallibility of the human condition, such as the one of legislators. Why assume that legislators are infallible? In addition, legislators do not have a final say and legislation does not count as finality. Why suppose that legislators are final? ${ }^{39}$ Nonetheless, judges are also human,

39 Waluchow, Inclusive Legal Positivism, supra note 2, at 252: "We might grant that within an ideal world in which legislators have sufficient time and energy to deal properly with hard cases, it would be better if they, and not judges, performed the delicate balancing of social aims, purposes, and principles such cases typically require. But of course in our less than perfect world, legislators have neither the time nor the energy to acquaint themselves adequately with all the facts and all 
fallible as well and, as a result, not entitled to the final say, either. Hence, it is necessary to keep the process open, i.e. revisable in case-by-case scenarios and from-time-to time, by judges and legislators, including framers, amenders or reformers, and of other legal officials and operators, such as lawyers and citizens. All of which reinforces the need for an adequate balance between fixity and flexibility. ${ }^{40}$

To the extent that it is not true that the people-then governs the people-now or the dead hand of the past governs the living will of those alive in the present and those to be born in the future, since it is really the people over time who governs. Even if Thomas Jefferson's famous statement was directed only to the idea that every generation is entitled to have its own constitution, it provides a sound argument for the claim that it is the people over time who governs: 41

Each generation is as independent of the one preceding as that was of all which had gone before. It has then, like them, a right to choose for itself the form of government it believes most promotive of its own happiness; consequently, to accommodate to the circumstances in which it finds itself, that received from its predecessors; and it is for the peace and good of mankind, that a solemn opportunity of doing this every nineteen or twenty years should be provided by the Constitution; so that it may be handed on, periodical repairs, from generation to generation, to the end of time, if anything human can so long endure.

It is true not only that any generation is as independent as the next but also that every generation has the same

the implications of all hard cases. Even if they were somehow able to make the necessary time, there is little doubt that the wheels of government and justice would be forced to turn far more slowly than we should find acceptable. So given these practical considerations, it seems to follow that judges and not legislators are our best hope in dealing with hard, penumbral cases."

40 Cfr. Brandeis, Louis D., "Experimentation and Man", in The Words of Justice Brandeis, supra note 36, at 76 and 128: "Man is weak and his judgment is at best fallible."

41 Jefferson, Thomas, "Letter to Samuel Kerchival (Monticello, July 12, 1816)”, in The Essential Thomas Jefferson, 314 (John Gabriel Hunt ed., 1994). 
right to choose for itself. But for that purpose a generation has to meet certain requirements to pass either a legislative bill with an absolute majority or a constitutional amendment by a supra-majority of two thirds in both chambers of Congress plus a supra-majority of three fourths in the state legislatures or ratifying conventions, as in the United States of America. In that sense, if those requirements are not met, it is not actually the case that the people-then that govern the people-now, but the latter which failed not to govern but to meet such requirements. Analogously, if a piece of legislation is held unconstitutional, it is not really the case that the judge prevails over the legislator, but the latter which failed not to govern but to legislate in a constitutional manner. However, nothing precludes the people-now from trying to meet the requirements nor prevents the legislator from trying to legislate in a constitutional mode, again and again. Contrary to the belief that judges - or people-then - are both final and infallible, it is clear that in a Constitutional Democracy, no one is final and infallible, much less has an absolute or ultimate authority. ${ }^{42}$

In Waluchow's terms (173): "Charters transform complex issues of political morality... into "them-against-us" battles", when what is required is quite the opposite, i.e. "open discussion, the ability to see the other side's point of view, and ultimately compromise and mutual accommodation." If there appears to be disagreement all the way down, should not we start looking for the existing agreement - or for constructing it - not only all the way up by judges but also all the way down, at least to some extent, by legislators themselves? In fact, in his words: "This is one very good reason why modern systems of government opt for a division of la-

42 Vid. Bishop Benjamin Hoadly (sermon before the English King in 1717) quoted by John Chipman Grey, "A Realist Conception of Law", in Philosophy of Law, 50 (Joel Feinberg and Hyman Gross eds., 3rd ed., 1986): "Whoever hath an absolute authority to interpret any written or spoken laws, it is he who is truly the Law-giver to all intents and purposes, and not the person who first wrote or spoke them". Vid. also Justice Robert H. Jackson (concurring opinion in) Brown v. Allen, 344 U.S. 443, 540 (1953): "We are not final because we are infallible, but we are infallible only because we are final." 
bour between legislatures and courts." (262) What's more (269-270):

Seen in this light, judges and legislators need not be seen to be in competition with each other over who has more courage or the better moral vision. On the contrary, they can each be seen to contribute, in their own unique ways, from their own unique perspectives, and within their unique contexts of decision, to the achievement of a morally sensitive and enlightened rule of law... judicial review sets the stage for a "dialogue" between the courts and the legislature... not as an imposition that thwarts the democratic will but as one stage in the democratic process.

Therefore, in a Constitutional Democracy, due to the fact that no one is final or infallible, what we need is neither a diktat from one to the other or vice versa, nor a final arbiter or referee, but a better understanding of the dialectical and dialogical relationship between courts and legislatures, including framers, amenders or reformers, as well as other legal officials and operators, such as lawyers and citizens, in the search for the community's constitutional morality -as a Rawlsian overlapping consensus via reflective equilibrium. (221) As Waluchow puts it (225-226):

Why should judges in deciding moral questions under a system of judicial review be required, for reasons of democracy, fairness, and the like, to respect the community's moral opinions on the matter - as opposed to the community's true moral commitments in reflective equilibrium? Why should they bend to the community's inauthentic wishes, not its authentic ones?... [J]udges are not philosopher-kings with a pipeline to moral truth. But they may well be in a very good position to determine the requirements of a community's true moral commitments and authentic wishes in particular cases. If this is so... then there is nothing amiss in asking judges to enforce these commitments and wishes against the mere opinions and inauthentic wishes of a possibly misguided public gripped by evaluative dissonance. This is no 
more problematic than acknowledging the duty of responsible legislators... to do the same.

In consequence, Waluchow is absolutely right in suggesting both that the Charter need not to be conceived as declaring "The Hubristic Message" (246): "We know which moral rights count, why they count, and the many complex ways they count in the myriad circumstances of politics ..."; and, that it may be saying quite the opposite "The Humble Message" (id.): "We do not know, with certainty, which moral rights count, why they count, and in what ways and to what degree they count in the myriad circumstances of politics...".

The different institutional forces and requirements that come into play to check not only the fallibility and finality but also the fixity and flexibility, in the case of México, include:

1) Legislation has to be passed by an absolute majority (i.e. $50 \%+1$ ) of the members present in both chambers of Congress, discussing and approving it sequentially (article 72), whereas a constitutional amendment or reform has to be passed —as we already indicated - by a two thirds supra-majority (i.e. $66.66 \%)$ of the members present in both chambers of Congress, discussing and approving it successively, plus ratified by the absolute majority (i.e. $50 \%+1$ ) of the legislatures of the states (article 135);43

43 Elsewhere I have pointed out that different forms of legislation, including the enacted properly by a legislative assembly and a constitutional amendment or reform, have different institutional forces and requirements. Vid. Flores,Imer B., "Legisprudence: The Forms and Limits of Legislation", 1 Problema. Anuario de Filosofia y Teoría del Derecho, 247, 266-268 (2007). (Earlier versions appeared in 1 Proceedings of the 22 $2^{\text {nd }}$ IVR World Congress Granada 2005: Legal Theory / Teoría del derecho. "Legal Positivism and Conceptual Analysis / Positivismo jurídico y análisis conceptual”, 106 Archiv für Rechts - und Socialphilosophie (ARSP), 194, 197-199 (José Juan Moreso ed., 2007); and, as "Lon L. Fuller's Implicit Laws of Lawmaking: The Forms and Limits of Legislation”, 5 De Legibus. Revista de Harvard Law School Association of Mexico, 83, 92-96 (2006)). 
2) Legislation can be vetoed by the president and the veto can be overridden by a two thirds supra-majority (i.e. 66.66\%) of the members present in both chambers of Congress, also by discussing and approving it one after another (article 72), whereas a constitutional amendment or reform cannot be vetoed, since it appears to be already overruled ex ante by the two thirds requirement; 44

3) Legislation itself, a constitutional amendment or reform, and their further applications by legal officials can be subjected to Judicial Review, but to have a general (derogatory) effect in some cases - as we already mentioned - a vote of at least eight out of eleven justices (i.e. 72.72\%), that constitute the Supreme Court at large, or four out of five (i.e. 80\%), that constitute each one of the two benches is required (article 105);45 and

4) Legislation itself, constitutional amendments or reforms, can be passed - and subjected to Judicial Review - again and again until the criteria previously identified by the Supreme Court as the community's constitutional morality are met.

To demonstrate how these different forces and requirements interact, let me point out one case. In 2006, before that year's general election, the two main media companies were able to get out from the political parties represented in both chambers of Congress two different legislative bills promulgated to enhance their duopolistic powers in exchange for a favourable treatment for their candidates, spe-

44 Elsewhere I have pointed out that constitutional amendments or reforms, as forms of legislation, have certain limits and can be subjected to judicial review. Vid. Flores, Imer B., "Sobre las formas y los límites de la legislación: A propósito de la constitucionalidad de una reforma constitucional", in $1 \mathrm{El}$ estado constitucional contemporáneo. Culturas y sistemas jurídicos comparados, 271 (Diego Valadés and Miguel Carbonell eds., 2006).

45 Ibid., at 283. 
cially the presidential ones. The president in office, at that time, apparently, who was also hostage to the media interests, despite the call to veto the bills did not exercise such power. In the end after several months, it was a minority of senators, who successfully brought the decision to the Supreme Court. With one justice under medical license and with other having to excuse himself from taking part in the hearings and in the decision of the case, presumably, under pressure from the media, the Supreme Court in June 7, 2007 overturned the bills for establishing a monopoly -in this case a duopoly- prohibited by article 28 of the Mexican constitution, with an eight to one decision.

While preparing new drafts of those legislative bills to comply with the criteria set by the Supreme Court, the current members of Congress, in both Chambers, apparently, with the support of the present President, on September 13 of this same year, were able to pass a constitutional amendment or reform, mainly, on electoral campaigns but related to those bills. The decision almost unanimously met the two thirds requirement and held in the opposite direction of the previous bills, by limiting the power of the media during election years; regardless of the media and some private interest groups opposition, who are crying that the amendment or reform implies a form of censorship and as such a limit to their freedom of expression. Since a constitutional amendment or reform cannot be vetoed by the President and its has already been ratified by the absolute majority of the legislatures of the states, those opposing to it can only bring its constitutionality into question, specifically, regarding its application, to the Supreme Court, first, and even to the Inter-American Council or Court on Human Rights, later on.

Clearly, as Waluchow has stressed: "judges are relatively insulated from the pressures to which legislators are inevitably subject." (255) If is true that the pressures faced by the legislative - and even by the executive - can also reach the judiciary, it is also true that they are better positioned 
to resist them. However, nothing precludes the executive and the legislative of resisting as well on behalf of the true moral commitments of the community's constitutional morality.

To know that we know what we know, and know that we do not know what we do not know, that is true knowledge.

Nicolaus COPERNICUS

\section{CONCLUSION}

Finally, in my opinion with my friendly amendment to his alternative, Waluchow will be back railed on the right track again, indeed, with a Copernican revolution in our thinking and with a General Theory of Judicial Review and of Constitutional Democracy. To conclude, let me paraphrase Balkin: "We are all living [tree] constitutionalists now. But only some of us are willing to admit it." 46 Whether what that exactly means leaves two open questions: Are we all living tree Copernicans, i.e. Dworkinians, 47 Waldronians ${ }^{48}$ or Waluchownians, now? Are we all willing to admit it?

46 Balkin, Alive and Kicking..., supra note 2.

47 Marmor assesses the "constitutional theories [of Dworkin and Waluchow] are very similar". Marmor, "Are Constitutions Legitimate?", note 38, at $107 \mathrm{fn} 37$.

48 Waldron, first, assumes not only "that this... commitment to rights involves an awareness of the world wide consensus on human rights and on the history of thinking about rights" but also "that this commitment is a living consensus, developing and evolving as defenders of rights talk to one another about what rights they have and what those rights imply." Second, clarifies "I have argued in the past that judicial review should not be understood as a confrontation between defenders of rights and opponents of rights but as a confrontation between one view of rights and another view of rights." And, finally, concludes "The members of the community are committed to rights, but they disagree about rights. Most issues of rights are in need of settlement. We need settlement not so much to dispose of the issue - nothing can do that- but to provide a basis for common action when action is necessary." Waldron, "The Core of the Case Against Judicial Review", supra note 32, at 1365, 1366 and 1369. (Emphasis added.) 